\title{
The Making of Islamist-inspired Terrorism and It's Counter-terrorism in Indonesia
}

\author{
Mohammad Zaki Arrobi Universitas Gadjah Mada, Indonesia
}

\begin{abstract}
The study attempts to uncover the making of Islamist-inspired terrorism and its state-led counter-terrorism responses in the modern history of Indonesia. It argues that Islamist-inspired terrorism and its counter-terrorism have been inextricably linked in complex ways within political and historical contexts. Instead of regarding Islamist-inspired terrorism and counterterrorism as separated and unrelated entities, or perceiving the latter as just response to the former, it suggests that they have been intertwined and shaped each other throughout Indonesia's modern history. By discussing Islamist-inspired terrorism in the three Indonesian historical periods, namely the resurgence of Darul Islam during 1940-60s, the re-emergence of Darul Islam networks and its series of terrorist attacks in 1980s, and the Jemaah Islamiyahrelated terrorist activities in the 2000s as illustrative cases, the study has delineated the ways in which Islamist-inspired terrorism and its state-led counter-terrorism have been bound up within particular political, historical, and sociological context. In addition to that, the study also reveals that both Islamist-inspired terrorism and its state-led counter-terrorism have been shaped by the dynamic interplay of local, national, and global contexts.
\end{abstract}

Keywords:

Islamist-inspired Terrorism; Counter-terrorism; State; Political Islam

\section{INTRODUCTION}

The study aims to critically examine the dynamic relationship between Islamist-terrorism and counterterrorism in Indonesia's mod ern history. Rejecting the 'alarmist approach' that exaggerate what Mohammad Zakki Arrobi is a lecturer and researcher at Department of Sociology, Universitas Gadjah Mada, JI. Sosio-Justisia No. 2 Bulaksumur Indonesia Indonesia. His research interest about Islam, politics and terrorism. (zaki.arrobi@mail.ugm.ac.id). I am thankful for the insightful comments of the reviewers that assisted us to improve this paper. Also, I am very grateful for the feedbacks and discussion by conference participants at Department of Politics Universitas Negeri Semarang-Indonesia. A special thanks to Prof. Peter Fussey and Dr. Darren Thiel for inspiring me to write this article during my study at the University of Essex. The publication of this article was supported by the Department of Sociology UGM Yogyakarta. so-called 'the Islamist threat' in Indonesia, it attempts to offer a new understanding through the interrogation of both Islamistterrorism and state-led counter-terrorism within particular political and historical contexts in Indonesia.

By drawing insights from critical terrorism studies informed by poststructuralism and constructivism, it advocates that Islamist-terrorism and counterterrorism have intertwined and shaped each other throughout Indonesia's modern history. Rather than regarding Islamist terrorism and counterterrorism are two separated entities or perceiving the 
latter is just a response to the former, it in Indonesia namely the 'actor camp' and argues that Islamist-terrorism and the 'structural camp'. The first camp counterterrorism have been mutually focuses on comprehending the structure, constituted and bound up with the networks, organisations, ideologies, and political, historical, and sociological broader social support for Islamistcontext. terrorism in Indonesia (Azca, 2011;

The discussion starts by assessing the Bruinessen, 2002; Greg Fealy, 2004; current debates among scholars over ICG, 2003; Karnavian, 2015; Solahudin, Islamist-inspired terrorism in Indonesia. Then, it moves to the framework of critical 2013). They have tried to deeply probe what kinds of structure and network that terrorism studies informed by postunderpinning violent Islamist group since structuralism and constructivism that the formation era of the nation-state in emphasises the importance of political and historical contexts as well as the Indonesia to the Democratic era. For instance, Bruinessen (2002: 117-118) hegemonic discourses that form terrorism and counterterrorism.

Next, it presents the main chapter that discusses the Islamist-inspired terrorism and counterterrorism in three periods of Indonesia's modern history namely: during the revolutionary struggle against the Dutch colonialism and Sukarno era in 1947-1965, in the New Order of Suharto era during 1966-1998, and in democratisation period since 1998 until 2005. Finally, yet importantly, the conclusion will be presented at the end.

\section{THEORETICAL PERSPECTIVES}

\section{Beyond Actor and Structural Approach}

There are two camps of explanations to understand Islamist-inspired terrorism

explains that the radicalism of Islam has deeply rooted in two prominent Muslim organisations, namely Darul Islam (Islamic State) and Masyumi Party since the formation era of Republic of Indonesia in the 1940s.

Meanwhile, Solahudin (2013) based on his extensive work, surveys historical and ideological roots of terrorism in Indonesia, from the more traditionalist group of Darul Islam in 1940s to the emergence of the more globalist group of Jemaah Islamiyah in the late 1990s. Others studies have been conducted mostly focus on the role of Jemaah Islamiyah and its relationship with $A$ /Qaeda (Abuza, 2003; Barton, 2004; Gunaratna, 2002) 
A number of critiques have emerged as a response to the shortcomings of 'the actor approach'. It has been criticised for the inadequacy to address the wider context of political, cultural, and economic that enables the Islamist-terrorism to flourish in Indonesia (Sidel, 2006, 2007; Hadiz, 2008). In contrast to actor approach, the structural camp argues the need to take into account the question of social justice, marginalisation of Muslim communities, capitalist development, and global politics in comprehending Islamistinspired terrorism in Indonesia (V. R. Hadiz, 2008; Rahman \& Hadiz, 2017; Sidel, 2006, 2007).

For example, Hadiz (2008) emphasises that Islamist radicalism had been the product of capitalist development during the authoritarian Suharto's regime that excludes Muslim communities in the political and economic field. While Sidel (2007) tracks the history and the legacy of Western colonialism that marginalise Muslim society in Southeast Asia countries. He contends that this marginalisation had subjugated Muslim to Non-Muslims secular-elites as the product of discriminatory colonial rule (Sidel, 2007: 11-19).
The structural camp looks adequate when addressing the broader contexts in which Islamist terrorism emerges. Such an eminence cannot be found in the actor or network approach. However, structural camps could potentially fall into the pacification of subjects due to its tendency to comprehend radicalism and terrorism as the direct consequence of externally structural processes such as marginalisation, modernisation, and capitalist development (Zulaikha \& Douglass, 2008: 30). Consequently, there is no political agency within the radical groups that embrace terrorism as their method of struggle.

To remedy these shortcomings, using insights from critical terrorism studies that heavily influenced by post-structuralism and constructivism might be fruitful. Critical terrorism studies has been fruitful and insightful to comprehend terrorism and counter-terrorism in an unconventional point of view.

There are at least three useful insights of critical terrorism studies that have significantly contributed to the scholarly debates on terrorism studies. Firstly, critical terrorism studies that informed by post-structuralism and constructivism comprehends 'terrorism' and 'counterterrorism' as 'social construct' and 
'discursive reality'. It refused to accept 'terrorism' and 'counter-terrorism' as objective categories that really exist in the world. It considers that such a comprehensive and accepted definition of terrorism and counter-terrorism has never existed (Maskaliunaite, 2002: 49), and sometimes it is rejected due to the pejorative tendency (Jackson, 2011: 116).

Instead of accepting the conventional and uncritical definition of terrorism and counter-terrorism, critical terrorism studies approach informed by post-structuralism and constructivism gives more emphasis on 'politics of violence', the construction and labelling of terrorism by state. It regards both terrorism and counterterrorism are discursively constructed through language usages and social practices (Zulaikha \& Douglass, 2008). In post-structuralism's view, both 'terrorism' and 'counter-terrorism' should be regarded as 'discursive reality', or in a more constructivist approach 'terrorism' is 'what states make of it' (Heath \& Kelly, 2016)

Secondly, critical terrorism studies brings back the importance of state within the broader study of terrorism. Analyses of critical terrorism studies cannot be undertaken without interrogating state performances. As Heat-Kelly (2016: 143) has insisted that 'terrorism' plays a pivotal role in constructing and maintaining the image of state sovereignty, it is 'constitutive outsider' that state really needs it. In this respect, the state and non-state actors should be included to understand the nature of terrorism and counter-terrorism.

Given the importance of the state in (re)constructing terrorism and counterterrorism, the study comprehends terrorism and state-led counter-terrorism are mutually constitutive. It embraces the notion that regard counterterrorism and terrorism are mutually constitutive rather than exclusively separated (Holland, 2016; Innes \& Thiel, 2008; Lindahl, 2016). In that sense, the ways in which we perceive terrorism to a certain degree determine the ways we counter it (Crelinsten, 2009: 39).

Thirdly, critical terrorism studies has committed to putting emancipation at the heart of terrorism studies. It has opened spaces and possibilities in acknowledging potential emancipation dimension within terrorist's groups. Toros and Gunning (2009) have revealed that terrorism can be seen as the tip of an iceberg of social, political, economic, and human conflicts. In this sense, terrorism might be the 
response to this multi-layered conflict language, but it is "the structured totality within society.

resulting from the articulatory practice of a

It should be clear here that critical subject' (Laclau \& Mouffe, 1985: 105).

terrorism studies does not legitimise or

Accordingly, the study attempts to go support any act of violence. Instead, beyond both the actor approach and the emancipatory dimension within this structural approach by utilising insights approach means that 'studying contexts of terrorist violence' and 'identifying nonviolent voices of terrorist movement' is a necessity when we conduct a study of terrorism (Toros, 2016: 170). In a rather post-structuralism's sense, radicalism that might lead to terrorism can potentially have political agency and emancipatory from critical terrorism studies informed by post-structuralism and constructivism. With bear in mind this framework, the study looks to understand how the Islamist-inspired terrorism and counterterrorism have entangled within the particular political-historical contexts throughout Indonesia's modern history. dimension since it attempts to respond to vulnerabilities and uncertainties (Hiarej, Sugiono, Djalong, \& Hakim, 2011: 40).

In addition to that, terrorism and counterterrorism cannot be separated from their historical and political contexts. As Jackson (2005: 19) and Holland (2016: 427) suggest that counterterrorism and terrorism should be located within particular conditions of emergence and specific power relations that enable and constrain them. In this light, counterterrorism and terrorism are discourses that produced through articulatory of state practices, such as political project, security and foreign FINDINGS AND DISCUSSION Countering Darul Islam: From 'Political Solution' to 'Military Operation'

This chapter investigates the emergence and development of Darul Islam particularly in West Java during Indonesia's revolution era in 1940s-65. It is argued that the rise of DI in the political landscape of the post-Independence era signified the articulation of 'Islamism' as a master signifier that can be realised both in violent and in non-violent acts. Islamism here is regarded as 'a master of the signifier' that enables the Islamists to policy, and global politics. Here, particularly but not exclusively in the discourse is defined as broader than 
realm of political struggle (Sayyid, 1997: 46-47).

In the case of Darul Islam, Islamism was used to challenge the hegemonic project of nationalist-secular discourse promoted by nationalist and westernised elites in the early independence era. Meanwhile, DI-version of Islamism that took violence strategies including terrorism was responded by the state through different approaches determined by various historical and political contexts.

By looking at the historical trajectory and interplay between Darul Islam and state responses, this chapter argues that Darul Islam cannot be understood either as simply the 'root of Islamist-terrorism' as some scholars advocate or 'a separatist movement' as the official history teaches us. Rather, it should be understood within particular historical and political context in which Islamism -as a hegemonic political project in Indonesiahad emerged as a vehicle for political dissent both in resisting the late colonialism of Dutch and in contesting with secular-nationalist and leftist forces in the battlefield during state formation of the newly Republic of Indonesia. The narratives below will delineate further this thesis.
Darul Islam has frequently been portrayed as 'the origin of violence' in the pursuit of Islamist goal in Indonesia's history (Effendi, 2003). Its leader, Kartosuwirjo, had played a vital role in the organisation and had a long-standing record during Indonesia's independence struggle (Solahudin, 2013: 27-30). Thanks to the reputation for Islamist rebellion, his name has been widely used to gain Islamist supporters who aspire to uphold Islamic state and deemed as 'forefather' for the most notorious Jihadist group in Southeast Asia namely Jemaah Islamiyah (Formichi, 2012: 9).

Darul Islam originated from West Java, but later other regional rebellions had incorporated themselves into the movement such as from Aceh, South Borneo, South Sulawesi, and Central Java. It emerged in 1947 during the revolutionary struggle of Indonesia against the Dutch colonialism that tried to back to the archipelago. Amidst the guerrilla warfare in Java, Darul Islam became a social vehicle for some Muslim community in establishing a truly Islamic state that upholds Sharia law.

Darul Islam is a profoundly important movement not just because it was greatly influential during the revolutionary struggle but also it renders political 
imagination in the struggle for 'Islamic state' for the later generations in the next decades (Temby, 2010). Meanwhile, some scholars labelled Darul Islam as 'the root of Jihadism and terrorism' in modern Indonesia (Bruinessen, 2002; Solahudin, 2013).

This chapter contends that either 'separatism narrative' promoted by state official history or 'root of Jihadism' narrative endorsed by some scholars are insufficient in investigating why Darul Islam emerged in the early modern republic era. By looking at the politicalhistorical context, it is worth to argue that Darul Islam was a product of a combination of the guerrilla problem, the decline of the new republic, and the defeat of political Islam at the battlefield in defining new republic. From the very beginning, Darul Islam emerged as the consequence of Renville agreement that forced pro-Republican troops to withdraw from West Java based on Van Mook's line. It had placed Islamic troops such as Hizbullah (Army of God) and Sabilillah (Path of God) in West Java in a difficult situation, Kartosuwiryo, as the commander of this army, refused to leave West Java and urged to continue fighting the Dutch until gaining the victory (Dengel, 1995: 64).
These two Islamic troops had been the main supporters of Darul Islam in the next following years. The Renville agreement not just implied 'an implicit declaration of surrender' for the new Republic, but also led to the creation of 'Pasundan State' in West Java under the control of Dutch colonial (Dengel, 1995). As a consequence, it had spurred Kartosuwiryo to pursue his 'total war' against the 'infidel Dutch' (Elson \& Formichi, 2011: 475).

The origin of Darul Islam can be traced further in the disagreement and disappointment with the diplomacy struggle lead by nationalist elites such as Sukarno and Hatta. Elson and Formichi (2011) have successfully investigated the origin of Darul Islam that lies in the division between 'the diplomacy struggle' on the table among nationalist elites like Sukarno-Hatta and 'the armed struggle' on the ground among 'people army leaders' like Kartosuwiryo. Furthermore, Darul Islam can emerge under the circumstances in which the political and military vacuum as the consequence of the withdrawn of Indonesian National Army and the fall of the Republic after the second Dutch police action in 1948 (Elson \& Formichi, 2011). 
In this similar vein, other study conducted by Hiroko Horikoshi (1975) reveals that Darul Islam was an Islamist political struggle emerged in a time of revolutionary war and political chaos. In addition, Van Dijk (1981) corroborates the political dimension of Darul Islam when examining its offshores in Aceh, South Sulawesi, and South Borneo; he contends these movements had originated in the regional rebellion that challenges the centralisation of the new republic government rather than based on an 'unchanged Islamic ideology'.

The responses to Darul Islam from the Republic of Indonesia had been changed over time along with particular political and historical contexts. At the beginning of the emergence of Darul Islam, the new Republic had been vague and ambiguous toward it, the Republic still viewed Darul Islam as the "bulwark of the Republic' struggled against the 'Pasundan State' sponsored by the Dutch in the West Java (Elson \& Formichi, 2011: 474).

Nevertheless, the responses were varied along with the political forces and hegemonic discourses that form the government. For instance, during the Islamic party leadership (Masyumı) in 1949-1950, due to the closeness of ideological connection, Darul Islam was treated as a part of wider guerrilla problem that lead to the failure of "people troops' to integrate with the new republic, therefore, the solution should be 'political solution' and 'persuasive dialogue' (Elson \& Formichi, 2011: 483-484; Formichi, 2012: 154-156)

Such 'a political approach' had been changed gradually leading to the "military approach' since the nationalist cabinet took over in 1952. During the Ali Sastroamirjoyo cabinet in 1953, Darul Islam was defined as 'enemy of the state' and 'rebellion' that should be terminated by any tools of state (Formichi, 2012: 160). Since the political direction moved closer toward authoritarianism in line with the growing influence of military power, the state of war and emergency and martial law prevailed in the pretext to response rampant regional rebellions in 1957. At the same time, Islamist politics had significantly diminished after political fragmentation and the disbandment of Masyumi in 1960 (Fogg, 2012: 401404).

Finally, in 1959 Sukarno's declaration of 'the Guided Democracy' signifies what so-called by Herbert Feith (2007) as 'the Decline of Constitutional Democracy in Indonesia'. Under this 
Sukarno's authoritarianism left-leaning turmoil in 1965. After the 'failed coup' in regime, the military operation named Jakarta, General Suharto raised as the 'Pagar Betis Operation' (Human Fence new national leader that building 'New Operation) was launched in 1960. The Order' upon the systematic and massive very basic idea of this operation is elimination of hundreds of thousand PKI's utilising civilian people to isolate Darul members and its alleged supporters Islam supporters and cutting the logistics supply, the operation was successful, and Kartosuwiryo was captured in 1962 (Formichi, 2012: 168-169).

We can see that the emergence of $\mathrm{DI}$ had been underpinned by complex historical and political factors, ranging from the problem of guerrilla warfare, the fall of the new republic, and more importantly the political defeat of 'Islamism' in the early stage of postindependence era. Moreover, the ways in which the state responded to DI had been varied determined by particular political and historical conditions.

\section{The Mutation of Islamist-Terrorism and} State Repression

The military defeat of Darul Islam in 1962 had not marked as the end of this movement and its networks. Since the political structure had been radically changed in 1965, the Darul Islam rose again from the grave thanks to the new opportunity that was provided by the new during 1965-66 (Roosa, 2006).

This massacre occurred under the climate of the Cold War with the pretext of combatting 'state enemy'. One of the key supporters in this total eradication of leftist groups was the Darul Islam members. Given the Dl's members shared 'antiCommunist tendency' with the military, Ex-Dl's soldiers involved in the military-led operation in the Communist massacre under the Siliwangi Division Commanders in West Java (Solahudin, 2013: 47)

After its involvement in eradicating the communists, Darul Islam was deemed as 'the potential ally' for the military forces. This new status brought some Ex-

Dl's leaders in the strategic position both in the politics and in business sectors. For instance, Ex-DI leaders such as Ateng DJaelani became Bandung Municipality chairperson of the Association of Oil and Gas Company and Muhammad Hassan worked in State National Intelligence Body (Solahudin, 2013: 49). This collaboration had continued further in the 1970s.

political establishment after a political 
The state had assisted the Dl's policy, it immediately labelled this network in the 1970s to flourish again networks as 'Komando Jihad' and through political protection and financial conducted massive arrest in 1977 support. In 1970, the biggest reunion of approaching national election (Solahudin, Dl's supporters was held in Situaksan, 2013: 65-66).

West Java, with the support from military

The crackdown of 'Komando Jihad' establishment elites. They declared a joint precisely before the election raised 'a statement to support Golkar, Suharto's conspiracy theory' that view what somain political vehicle (Solahudin, 2013: called 'Komando Jihad' was the state 52-53). Behind this controversial creation to discriminate the United decision was the political manoeuvre of Development Party (PPP), the only Ali Moertopo -an intelligence elite- Islamic party allowed, as the main through State National Intelligence Body contender of ruling party (Muqoddas, (BAKIN) that attempted to control and to 2011). However, several evidences reveal use DI as a tool for Golkar's in gaining support in the election and antithat rather than 'a state manipulation', 'Komando Jihad' and its series of terrorist Communist campaign (Jones, 2010: 60).

It was evident that the state had attacks more appropriate to be considered as 'the unintended consequences' of the paved the way for the re-emergence of the 'unholy relationship' between state Dl's network during the 1970s. Through the financial and political support, DI had successfully transformed its organisational structure from 'armed guerrilla' to 'clandestine cell organisations'. With this revived networks, several terrorist plots had been conducted by the new DI members in Sumatera such as Bombing the Church, Christian school, Koran recitation event, and series of armed robbery during 1976 (Temby, 2010: 19). After this series of attack, the state started particularly through intelligence apparatus with the Ex-DI members (Conboy, 2003; Temby, 2010).

In addition to that, the resurgence of 'Dl-extended family' in the 1970 s was the product of both the Cold War social conflict and the rise of state authoritarianism (Rahman and Hadiz, 2017). By the social conflict of the Cold War, the elimination of leftist forces in 1965 enabled the violent-Islamist forces to re-build its buried networks thanks to to begin to consider 'the blowback' of its 
the political protection and financial ideology. It was a signal for the total support from the state.

eradication of Islam from politics

Meanwhile, by the rising highly (Formichi, 2012: 187). Muslim authoritarian regime led by Suharto, community had not only suffered from violent Islamism had become the only one political marginalisation but also alternative to express the discontent of economic exclusion since the large Islamist political forces. Suharto business was dominated by the Chinese established his regime with the massive minority ethnic that collaborate with de-politicization and demobilisation secular elites formed 'oligarchic circle' (V. project to ensure national stability and economic development (Crouch, 2007; Hadiz \& Robison, 2004).

These situations led to the Muslims' Gregor, 2007). In achieving this goal, the political frustrations that coincided with regime had systematically suppressed all of its political opponents, primarily Islamist forces after the total deprivation of leftist forces in 1965. Such repression manifested when the aspiration of Islamist leaders to rehabilitate Masyumi, as the biggest Islamic political party and the main channel for non-violent Islamism, was prohibited. Instead, the government forced to merge all different Islamic political groups into one corporatist party, namely the United Development Party (Effendi, 2004).

By the 1980s, the New Order regime had launched various draconian controls to suppress its political adversaries completely. It included new legislation that obliges all political parties and mass organisations to affirm 'Pancasila' the resurgence of global Islamism after the victory of the Islamic Revolution in Iran in 1979. Such frustration and anger were reflected in the defence plea of Abdullah Sungkar - DI member who became the first leader of Jemaah Islamiyah- who fiercely criticize Suharto's regime for 'Hijacking' Islamic party, manipulating election, treating 'Pancasila' as a sacred symbol, detaining Muslim preachers, and banning Muslim media (Jones, 2010: 43-44).

The absence of credible Muslim political channel merged with the growing influence of global Islamism had transformed Darul Islam into a new kind of regional Islamist network, namely Jemaah Islamiyah (JI). JI has an (National Ideology) as their sole basic with its predecessor. While Darul Islam 
combined a sort of 'local Jihadism' with 'Mystical aspects' of Sufi, Jemaah Islamiyah embraces 'Salafi-Jihadism' tendency with the vision of global Islamism (Jones, 2010; Solahudin, 2013).

JI started to be known in the mid1990s, but its activities began in the late 1980s. Under the leadership of two political exiles in Malaysia, namely Abdullah Sungkar and Abu Bakar Baasyir, $\mathrm{JI}$ recruited its cadres from various Islamist organisations and sent them to Afghanistan as military preparation to take over Suharto's regime once when they were ready (Solahudin, 2013). From Malaysia, they had frequently visited the Middle East, met with Osama Bin Laden, and built a new regional network of Islamist that was deemed by some scholar as 'the franchise of Al-Qaeda' in Southeast Asia (Abuza, 2003; Gunaratna, 2006).

From the point of view counterterrorism strategy, the co-optation of Darul Islam in an attempt to control and to gain its social base support in the election had been a terrible mistake (Jones, 2010: 39). It had ruined 'the community support approach' which was conducted by the Siliwangi Military Division after the military defeat of Darul
Islam in 1962, under this scheme ex-DI members were offered with transmigration programme, financial support, and employment opportunities (Temby, 2010: 26). As a result of this mistake, the unexpected consequences emerged that resulted in several terrorist attacks during 1970-80s and the establishment of a new regional violent-Islamist network in Southeast Asia in the late 1990s.

The narratives above demonstrate that the resurgence of DI-networks that resulted in a series of terrorist acts during 1980-90s can be regarded as the articulation of Islamism that had no space during Suharto's developmentalist regime. Ironically, the resurrection of Dl's extended family had been enabled by the state policies to accommodate and to use them in order to secure its developmentalist and depoliticisation projects.

\section{Political Islam in the Age of Global War on Terror}

While two previous chapters deal with the articulation of violent Islamism and how the state conducted its politics of violence toward them under the fragile new republic and authoritarian regime, this chapter discusses the fate of violentIslamism in the new democratic era. This 
chapter argues that particular sociological and political conditions during the critical time of power transition had enabled Jemaah Islamiyah to conduct its series of terrorist acts. Meanwhile, state-led counter-terrorism to Jemaah Islamiyah had been heavily influenced by the discourse of global war on terror led by the USA after $9 / 11$.

Indonesia has entered a new phase of the democratic era since 1998. Preceded with the Asian economic crisis in 1997 that followed by mass demonstrations and social unrests led to the resignation of Suharto after more than 32-years in the presidency. This dramatic change in May 1998 preceded and accompanied by the massive riots and religious violence across Java and many parts of the archipelago. John Sidel (2006) formulates three phases of religious violence in Indonesia from 1995 until 2005 namely riots (1995-97), pogroms (199-2001), and Jihad campaign (2001-2005).

Among this Jihad campaign, the Bali bombing in 2002 was the most significant attack that hugely attracted international attention. It deliberatively targeted publicity and symbolic site namely nightclubs that represent Western globalisation and moral decadence (Lewis, 2005: 168). It caused 202 people death mostly foreigners, including 88 Australians, 23 Britons, and 7 Americans (Park, 2013). Six days after the bombing President Megawati signed Anti-Terrorism Law (Butt, 2008). Unfortunately, it was just a start for the subsequent attacks, namely attack in American-hotel JW Marriot in 2003, Australian embassy attack in 2004, and Bali Bombing II in 2005.

These series of the attack were perpetrated by members of Jemaah Islamiyah, which operate through cells with loosely organised, and often ad-hoc structure (ICG, 2002). While JI as a regional terrorist organization has been widely studied by scholars particularly its origin, ideology, networks, and operations (Abuza, 2003; Barton, 2004; Gunaratna, 2006; Jones, 2010; Karnavian, 2015), the fundamental question why 'local Jihad' in religious conflict zones in the beginning 2000 transformed into 'international Jihad' targeting Western sites since 2002 remain underresearched (Sidel, 2007).

The answer might lie in the sociological, political, and discursive level during the transitional period. During 1999-2001, political Islam in Indonesia had experienced a dramatic and sudden change from 'temporary triumph' to the 
'fatal defeat' in a relatively short time. The victory of nationalist party (PDI-P) in the 1999 election, the rise of Megawati Sukarnoputri -a woman and secularnationalist leader- became president in 2001, the failure to re-insert Sharia law into national constitution in the parliamentary struggle, and crackdown on Muslims activists in Moluccas and Sulawesi by the state security services were manifestations of the political defeat of Islamist forces. It was a dramatic decline after previously Islamist forces gained momentum when successfully brought numerous Muslim figures into high-rank political elite positions along with the rising influence of Muslim middle class in the state bureaucracy, military, education, and professional associations since the mid-1990 (Hefner, 2000).

In short, rather than perceiving the series of terrorist attacks as the growing trend of Islamist forces, it should be understood as a symptom and reaction to the decline, domestication, and disentanglement of Islamist forces from state power (Sidel, 2007). Therefore, the turn of Islamist militants to terrorism reflects both new constellation of power and an attempt to bring back the viability of Islam at the moment of declining (Sidel, 2007: 27). The defeat of political
Islam in the struggle for power coincided with the re-emergence of oligarchic politics (V. Hadiz \& Robison, 2004; Winters, 2011), which is characterized by money politics, clientelism, and patronage (Aspinall \& Sukmajati, 2016) and at the same time the advent of Global War on Terror led by the USA that put pressure on the Indonesia's government (Capie, 2004).

Meanwhile, after 2005, the Jl's network had been weakened, and it turned its activity into 'individual Jihad' due to the crackdown of the government and to a less degree internal fragmentation (Solahudin, 2013: 200). This new 'individual trend' is operated by targeting police for the revenge of crackdown and arrest by the police over the years. Such a new direction manifested in attack on Hamparan Police station in 2010, bombing police mosque in Cirebon in 2011, suicide bombing in Solo police station in 2016, and the first ISIS-inspired terrorist attack in Southeast Asia, Sarinah-Jakarta attack, targeted police station at the beginning of 2016 (Singh, 2016; Solahudin, 2013: 200).

While Islamist terrorist attacks have much to do with the changing constellation in the political, sociological, and discursive level, Indonesian 
responses toward terrorism, particularly after Bali Bombing in 2002, have been profoundly shaped by the global discourse of war on terror led by the USA. The USled global war on terror has been the most significant external factor that determines Indonesia's counterterrorism after the Bali Bombing.

With the USA status as the sole hegemon, the US policy on security after 9/11 go beyond the Middle East or Afghanistan but reaching out every corner in the earth (Hershberg \& Moore, 2002: 5). Moreover, the campaign of global war on terror not just influencing global arrangement on security and foreign policy, but also in the pervasive 'cultural talk' that divide Muslims in the world into two categories, namely 'Good Muslim' who are the moderates and depoliticized Muslims and 'Bad Muslim' who are the Islamists and the Radicals (Mamdani, 2002: 44). Here Islam is re-orientalised through the discourse of terrorism that served the liberal security and order establishment (Djalong, 2010).

Indonesia, like other countries in the world, has not been immune from such a hegemon's influence. From the very beginning, the pursuing of militant Islamists in conflict zones like Moluccas and Poso in 2000-2001 had been encouraged by the US-led global war on terror (Sidel, 2007: 26). The responses toward Islamist-inspired terrorism in this period had been greatly influenced by the global war on terror proponents especially the USA and Australia. With the advent of the Bali bombing, foreign assistance had increased sharply from the USA, Australia, Japan, and Singapore. For instance, Indonesia had been a major recipient of the US Anti-Terrorism Assistance (ATA), through this program, the Indonesia police personnel were trained, and it spent financial assistance until more than $32 \$$ million during 20022007 (Wise, 2005: 67). Not only training and funding, but the US also assisted in establishing 'Special Detachment 88', a counterterrorism force that plays a pivotal role in Indonesia's counterterrorism (Wise, 2005: 67-68).

Meanwhile, Australia, as the neighbouring country who suffer the biggest casualty in the Bali bombing, deems Indonesia as the 'front line' in the global war on terror. Consequently, Australia further influenced Indonesian policy in addressing Islamist-terrorism. Australia's influence had been various from financial assistance, police training, intelligence cooperation, regional cooperation, and establishing a Centre for 
Law Enforcement Cooperation in Jakarta (Wise, 2005: 73-75). The body is a regional centre that aims 'to provide operational support and professional guidance in response to specific terrorist threat', which was funded by Australia approximately $27.7 \$$ millions for five first year (Wise, 2005: 76). In the regional level, Association of Southeast Asian Nations (ASEAN) had been a close ally for the US-led global war on terror in this precarious region; the US has cooperated with ASEAN ally to enhance the state capacity and intelligence sharing (Ramakhrisna, 2005).

Since the global war on terror not just rely on the war on the battleground through military and intelligence forces but also the 'battle of ideas' through social and political agencies (Blain, 2012; Jarvis, 2009), the Indonesia's war on terrorism renders this strategy by combining 'hard approach' and 'soft approach'. While the hard approach has primarily operated through 'Special Detachment of 88', the soft approach manifested in more subtle ways.

Among various channels, the National Counterterrorism Agency (BNPT) that established in 2010 could represent the hub for 'the soft approach' activities. BNPT has focused its activity on de- radicalization and counter-radicalisation through alignment with the moderate Islam groups in Indonesia (Fealy, 2017: 24). Other channels such as supporting cultural exchanges and interfaith dialogs among religious leaders, campaigning a liberal version of Islam through NGOs like 'Islamic Liberal Networks' (JIL), and aligning with moderate Muslim mass organizations such as Nahdatul Ulama and Muhammadiyah (Borgu, 2005: 75; Rabasa, Sickle, Benard, \& Schwartz, 2007: 105).

Nowadays, Indonesia's counterterrorism has been considered as one of the best counterterrorism groups in the word due to its robust and effective performance of police in apprehending, prosecuting, and disrupting terrorists (Allard \& Kapoor, 2016; Fealy, 2017; Gunaratna, 2017). Such an impressive performance cannot be separated from the vital instrument of Indonesia's counterterrorism, namely Special Detachment 88 that successfully arrested at least 800 'Jihadists' since 2002 and it has foiled 15 attacks and arrested more than 150 convicted for the last year alone (Allard \& Kapoor, 2016; Fealy, 2017: 24).

Despite its success story, the Special Detachment 88 has suffered from 
accusation for human right violations from several NGOs; these included unlawful killings, arbitrary detention, and torture of terrorist suspects (Istiqomah, 2015: 161). Such alleged human right violations spark criticisms from Islamic organisations (Priamarizki, 2013). Furthermore, the recent counterterrorism operation in combatting Mujahidin Indonesia Timur (MIT) in Sulawesi have allowed the increasing role of Military power in Indonesia's counterterrorism (Glassman, 2005; Singh, 2016).

\section{CONCLUSION}

The study reveals that Islamistinspired terrorism has closely intertwined with the state-led counter-terrorism throughout Indonesia's modern history. By focusing on the sociological, political, and discursive level, it concludes that Islamist-inspired terrorism and counterterrorism have mutually constituted and bound up with the particular political and historical contexts. From this point of view, Islamist-inspired terrorism and counterterrorism cannot be strictly separated into two different entities. Instead, it should be understood as mutually constitutive in which each element shapes each other in complex ways within political and historical contexts.

In proposing such an argument, the study has investigated three historical periods in Indonesia in which Islamistinspired terrorism and counterterrorism are socially and discursively constituted. First, Darul Islam emerged as the politicoreligious struggle against Dutch colonialism and the secular adversaries (nationalist and communist) in the battle to define the new Republic. While the state responses had been varied shaped by the hegemonic political discourse and establishment, ranging from 'political solution' under the Islamic party leadership to 'military operation' under Sukarno left-leaning authoritarianism. Second, the resurrection of Darul Islam networks and its series of terrorist attack in 1970-80s were the product of state ambivalence and the Cold War social conflict. More ironically, the ambivalent state response toward them had sparked unintended and fatal consequences as manifested in a series of terrorist attack in 1970-80s.

Lastly, it contends that a series of terrorist attacks that targeted Western sites since 2002-2005 were an attempt by militant-Islamists to restore the viability of Islam after their dramatic defeat. 
Meanwhile, Indonesia's counterterrorism after the Bali bombing had been profoundly shaped by the discourse of global war on terror led by the USA. It consists of a hard approach (high policing) by military and intelligence service and the soft approach that mobilise civil society organisations in the fight against the political ideology of violent Islamism.

\section{REFERENCES}

Abuza, Z. (2003). Militant Islam in Southeast Asia: Crucible of Terror. London: Lynne Rienner Publishers.

Abuza, Z. (2007). Political Islam and Violence in Indonesia. London and New York: Routledge.

Allard, T., \& Kapoor, K. (2016). Fighting back: How Indonesia's elite police turned the tide on militants. Retrieved March 25, 2017.

Aspinall, E., \& Sukmajati, M. (2016). Electoral Dynamics in Indonesia: Money Politics, Patronage and Clientelism at the Grassroots. Singapore: NUS Publisher.

Azca, N. (2011). After Jihad: A Biographical Approach to Passionate Politics in Indonesia. Universiteit van Amsterdam.
Barton, G. (2004). Indonesia's Struggle: Jemaah Islamiyah and the Soul of Islam. South Wales: UNSW Press.

Blain, M. (2012). Power, Discourse, and Victimage Ritual in the War on Terror. Surrey: Ashgate Publishing Company.

Borgu, A. (2005). Local Jihad: Radical Islam and terrorism in Indonesia. Barton ACT.

Bruinessen, M. van. (2002). Genealogies of Islamic radicalism in post-Suharto Indonesia. South East Asia Research, 10 No 2, 117-154.

Busyro Muqoddas. (2011). Hegemoni Rezim Intelijen Sisi Gelap Peradilan Kasus Komando Jihad. Yogyakarta: PUSHAM UII.

Butt, S. (2008). Anti-Terrorism Law and Criminal Process in Indonesia. Melbourne.

Capie, D. (2004). Between a hegemon and a hard place: the "war on terror" and Southeast Asian-US relations. Pacific Review, 17, 223-248.

Conboy, K. (2003). Intel: Inside Indonesia's Intelligence Service. Jakarta and Kuala Lumpur: Equinox Publishing.

Crelinsten, R. (2009). Counterterrorism. Oxford: Willey. 
Crouch, H. (2007). The Army and Politics in Indonesia. Jakarta and Kuala Lumpur: Equinox Publishing.

Dengel, H. H. (1995). Darul Islam dan Kartosuwiryo: Langkah Perwujudan Angan-Angan yang Gagal. Pustaka Sinar Harapan.

Dijk, K. Van. (1981). Rebellion under the Banner of Islam: the Darul Islam in Indonesia. The Hague: Nijhoff: KITLV Press.

Djalong, F. (2010). Reorientalising Islam: Terrorism and Discourse on Evil. Jurnal Sosial Politik, 14(2).

Effendi, B. (2003). Islam and the State in Indonesia. Singapore: ISEAS Publishing.

Effendi, B. (2004). Islam and the State in Indonesia. Ohio: Ohio University Press.

Elson, R., \& Formichi, C. (2011). Why did Kartosuwiryo start shooting? An account of Dutch-Republican-Islamic forces interaction in West Java, 1945-49. Journal of Southeast Asian Studies, 42 (3), 458-486.

Fealy, G. (2017). Counterterrorism Yearbook 2017. Barton ACT.

Fogg, K. (2012). The Fate of Muslim Nationalism in Independent Indonesia. The University of Yale.
Formichi, C. (2012). Islam and the Making of Nation: Kartowuswiryo and Political Islam in twentieth -century Indonesia. Leiden: KITLV Press.

Glassman, J. (2005). The "War on Terrorism" comes to Southeast Asia. Journal of Contemporary Asia, 35(1).

Greg Fealy. (2004). Islamic Radicalism in Indonesia: The Faltering Revival. Southeast Asian Affairs, 104-121.

Gregor, K. M. (2007). History in Uniform: Military Ideology and the Construction of Indonesia's Past. Singapore: NUS Publisher.

Gunaratna, R. (2002). Understanding Al Qaeda and its Network in Southeast Asia. In K. Ramakrishna \& S. S. Tan (Eds.), After Bali: the Threat of Terrorism in Southeast Asia. Singapore: Nanyang Technological University.

Gunaratna, R. (2006). Terrorism in Southeast Asia: Threat and Response. Gunaratna, R. (2017). Counter Terrorist Trends and Analyses. Singapore.

Hadiz, V. R. (2008). Towards a Sociological Understanding of Islamic Radicalism in Indonesia. Journal of Contemporary Asia, 38 (4), 638647.

Hadiz, V., \& Robison, R. (2004). Reorganising Power in Indonesia: The 
Politics of Oligarchy in an Age of Markets. Hongkong: Routledge.

Heath-Kelly,

C. (2016)

structuralism and constructivism. In

R. Jackson (Ed.), Routledge Handbook of Critical Terrorism Studies. London, New York: Routledge.

Hefner, R. (2000). Civil Islam: Muslims and Democratization in Indonesia. New Jersey: Princeton University Press.

Herbert Feith. (2007). The Decline of Constitutional Democracy in Indonesia. Jakarta and Kuala Lumpur: Equinox Publishing.

Hershberg, E., \& Moore, K. (2002). Introduction: Place, Perspective, ad Power: Interpreting September 11. In Critical Views of September 11 : Analyses from Around the World. New York: New York Press.

Hiarej, E., Sugiono, M., Djalong, F. V., \& Hakim, L. (2011). Terrorism, Radicalism, and Violence: Conceptual Development. Jakarta.

Holland, J. (2016). The language of Counterterrorism. In Routledge Handbook of Critical Terrorism Studies. New York: Routledge.

ICG. (2002). Indonesia Backgrounder: How the Jemaah Islamiyah Terrorist
Network Operates. Jakarta and Brussel.

CG. (2003). Jamaah Islamiyah in Southeast Asia. Jakarta and Brussel. Innes, M., \& Thiel, D. (2008). Policing Terror. In Handbook of Policing. London: Routledge.

Istiqomah, M. (2015). In the Name of Counter-Terrorism: Human Rights Abuses in Indonesia. Asia Pacific Journal of Advanced Business and Social Studies, 1(1), 157-167.

Jackson, R. (2005). Writing the War on Terrorism: Language, Politics, and Counter-Terrorism. Manchester:

Manchester University Press.

Jackson, R. (2011). In defence of "terrorism": finding a way through a forest of misconceptions. Behavioral Sciences of Terrorism and Political Aggression, 3, 116-130.

Jarvis, L. (2009). Times of Terror: Discourse, Temporality, and the War on Terror. Hampshire: Palgrave MacMillan.

Jones, S. (2010). New Order Repression and the Birth of Jemaah Islamiyah. In E. Aspinall \& G. Fealy (Eds.), Soeharto's New Order and its Legacy: Essays in honour of Harold Crouch. Canberra: ANU Publisher. 
Karnavian, T. (2015). Explaining Islamist Insurgencies the Case of al-Jamaah al-Islamiyyah and the Radicalisation of the Poso Conflict, 2000-2007. London: Imperial College London Press.

Laclau, E., \& Mouffe, C. (1985). Hegemony and Socialist Strategy: Towards a Radical Democratic Politics. London: Verso.

Lewis, J. (2005). Language: the Role of Media and Culture in Global Terror and Political Violence. London: Pluto Press.

Lindahl, S. (2016). Critical Evaluation of Counterterrorism. In Routledge Handbook of Critical Terrorism Studies. New York: Routledge.

Mamdani, M. (2002). Good Muslim, Bad Muslim: A Political Perspective on Culture and Terrorism. American Anthropologist, 104 No 3(September 2002), 766-775.

Maskaliunaite, A. (2002). Defining Terrorism in the Political and Academic Discourse. Baltic Defence Review, 8, 36-50.

Park, A. (2013). Bali bombings: Full list of victims' names.

Priamarizki, A. (2013). Counter-Terrorism in Indonesia: The End of Special Detachment 88? Singapore.
Rabasa, A., Sickle, P., Benard, C., \& Schwartz, L. (2007). Building Moderate Muslim Networks. Virginia. Rahman, A., \& Hadiz, V. (2017). Three Islamist Generations, one Islamic State: the Darul Islam movement and Indonesian social transformation. Critical Asian Studies, 49, 54-72.

Ramakhrisna, K. (2005). The Southeast Asian Approach" to CounterTerrorism: Learning from Indonesia and Malaysia. Journal of Conflict Studies, 27-47.

Roosa, J. (2006). The pretext for Mass Murder: The September 30th Movement and Suharto's Coup d'État in Indonesia. Wisconsin: The University of Wisconsin Press.

Sayyid, B. (1997). A Fundamental of Fear: Eurocentrism and the Emergence of Islamism. London and New York: Zed Books Ltd.

Sidel, J. (2006). Riots, Pogroms, Jihad: Religious Violence in Indonesia. Ithaca and London: Cornell University Press.

Sidel, J. (2007). The "Islamist Threat" in Southeast Asia: A Reassessment. Singapore: ISEAS Publishing.

Singh, J. (2016). Operation Tinombala: Indonesia's New Counter-Terrorism Strategy. Singapore. 
Solahudin. (2013). The Roots of Terrorism in Indonesia: From Darul Islam to Jemaah Islamiyah (Cornell Un). Ithaca and London.

Temby, Q. (2010). Imagining an Islamic State in Indonesia: From Darul Islam to Jemaah Islamiyah. Indonesia, 89 , $1-36$.

Toros, H. (2016). Critical Theory and Terrorism Studies: Ethics and Emancipation. In R. Jackson (Ed.), Routledge Handbook of Critical Terrorism Studies. London; New York: Routledge.

Toros, H., \& Gunning, J. (2009). Exploring a critical theory approach to terrorism. In R. Jackson, M. B. Smyth, \& J. Gunning (Eds.), Critical Terrorism Studies: A New Research Agenda. London and New York: Routledge.

Winters, J. (2011). Oligarchy. Cambridge: Cambridge University Press.

Wise, W. (2005). Indonesia's War on Terror. New York.

Zulaikha, J., \& Douglass, W. (2008). The terrorist subject: terrorism studies and the absent subjectivity. Critical Studies on Terrorism, 1, 27-36. 